\title{
1. Introduction: Co-ordinating demand and supply of law: Market forces or state control?
}

\author{
Jean-Michel Josselin and Alain Marciano
}

\section{INTRODUCTION}

The idea that competition plays an important role in the provision of law has gained an indisputable legitimacy among economists. It does not only convey the acknowledgement of the influence of rules and institutions on economic competition, but also that governments, when institutional competition is at stake, or legal producers, in the case of legal competition, are rivals and compete just like producers of goods and services compete in usual markets. In other words, if we admit that rules are goods that must be produced (and not simply discovered by judges), then their provision must be organized according to market mechanisms. Thus, legal competition, as a decentralized market process of provision of law in which legal clubs compete, can be contrasted with a monopolist and centralized lawmaking process, mainly backed up by the coercive power of the State. Even if the contrast between these two models is not so neat in reality, where practices mix with reasoned arguments, these approaches nonetheless constitute two theoretical references that allow us to understand and to model many important situations in which new institutions have to be elaborated. Besides the building of new legal systems in the former communist countries or the provision of law in cyberspace, the harmonization of law related to the European integration process is certainly one of the major issues to be discussed. This is the focus of the chapters presented in this volume.

The example of the European Union is all the more interesting in that it clearly illustrates the relationship between legal competition and the interrogations about future federalism: when several local (or national) jurisdictions are granted with the right to produce legal rules, it is indeed crucial to know if these clubs must be located on the same level - competition remains horizontal - or may be located on different levels - competition is both horizontal and vertical. Therefore, if competition in the legal market works without notable failures, then there is no necessity to assign legal responsibilities to the central 
governmental level and competition may remain horizontal. In this perspective, a confederation is the most appropriate constitutional framework. By contrast, when there exist limitations on market mechanisms or market failures, it becomes necessary to assign legal responsibilities to the central level and competition involves different institutional levels: a federation is the regime corresponding to such a situation. In other words, a confederation corresponds to a competitive system - perfect or not -, while federalism implies, besides competition, State intervention, some degree of centralization and procedures of harmonization.

With regard to the present situation in Europe, it may remain possible to choose between these two contrasted models: even if centralization has made its way through the process of integration, it still seems possible and it could be preferable to envisage a constitutional structure based on a decentralized and competitive provision of legal rules. Such is the argument put forward by the advocates of legal competition, by insisting upon the benefits that European citizens could draw from this competition. They stress that, by analogy to what happens in ordinary markets, competitive pressures on the market for rules should stimulate innovation and sophistication in legal rules and also motivate lawmakers 'to compare their own legal products with those available in competing jurisdictions' (Ogus, 1999, p. 409), 'to adapt their products' (ibid.) and to imitate the innovations made by the leading jurisdictions. As a consequence, legal competition ensures the elimination of inefficient rules, prevents, if not precludes, predatory behaviours and unjustified wealth transfers by the central level. It also guarantees the respect of individual preferences - since the problems are dealt with at the smallest (and supposedly most appropriate) institutional level. Therefore, undoubtedly, legal competition should define the organization of the future legal organization. In other words, decentralization should be the 'rule' (Van den Bergh, 2000) or 'the starting point' (Faure, 2000) and centralization the exception.

In counterpoint, usual criticisms against legal competition deal with its effects. The argument that benefits may not systematically outweigh costs is of course far from trivial, but it should come at a second stage. The first one should examine the reality of competitive pressures in the field of law. To put it differently, before enquiring into the efficiency of legal competition, one must make sure that such competition does or can exist. In this perspective, the major problems come from the possibility of arbitrage between the different legal regimes. Indeed, citizens must have the opportunity to compare and then to choose the legal system that is most appropriate to their needs and preferences. Legal arbitrage is then related to the existence of enough legal regimes to guarantee the effectiveness of competition and to make sure that individuals can find rules corresponding to their preferences. The more numerous legal clubs are, the easier arbitrage is and the more competitive is the market. 
However, an elastic supply in legal clubs is not an easy condition to verify. Thus, an analysis of the merits and virtues of legal competition has primarily to concentrate on the conditions which permit legal arbitrage. It is only within this set of conditions that the positive or negative consequences of competition can be analysed. It may well be that, most of the time, legal arbitrage must then give way to the intervention of the state.

The chapters that constitute this volume are presented in the perspective of the debate over the merits of, and conditions for, a competitive provision of law, with a special focus on the European Union. These chapters contribute to an economic theory of legal competition in that they deal with three major aspects of the competitive provision of legal rules. The first section concerns the conditions under which citizens and firms arbitrate between the different legal orders. This section presents the problem of legal competition from the demand side of the market and in particular the chapters that analyse the conditions required for the respect of the sovereignty of the citizens. The second aspect concerns the answers and reactions by the producers of legal rules. Here, the problem is analysed from the supply side of the legal market: the second section presents the chapters relating to the consequences of the competitive pressures on the behaviour of the lawmakers. As to the third aspect, justifications must be given to the intervention of the state. The last section finally presents the chapters discussing the conditions under which it may efficiently control the process of law provision.

\section{LEGAL ARBITRAGE AND THE CONDITIONS FOR AN EFFECTIVE COMPETITION IN THE PROVISION OF LAW}

In order to make a difference between the situations in which arbitrage is possible or not, it is useful to refer to a criterion put forward by Ogus, who proposes 'to distinguish situations in which legal rules can be envisaged as a homogeneous product [...] from those in which it has heterogeneous qualities' (1999, p. 406). Now, if arbitrage, and thus competition, are difficult if not impossible in the case of heterogeneity between the different legal clubs, it does not imply that legal arbitrage is without any problem when legal products are homogeneous. On the contrary, information costs and in addition transaction costs raise difficulties.

\section{Heterogeneous Legal Clubs and Asymmetries of Information: the Difficulty of Legal Arbitrage}

The diversity of specialized legal clubs could be presented as a necessary condition for a genuine competition between legal clubs. By contrast, when a 
monopoly is granted with the responsibility to create legal rules, the absence of different sources for the law by definition prevents any arbitrage. ${ }^{1}$ However, the existence of several, diverse and specialized legal clubs may prevent or discourage legal arbitrage. It happens, in particular, when diversity turns into heterogeneity. Arbitrage is then useless and competition does not make sense.

There are two possible situations in which legal rules have, or are perceived as having, heterogeneous qualities. First, when the differences between the competing legal cultures are too large to be bridgeable and, second, when there exists imperfect and asymmetric information. In these two cases, comparison is not a matter of the quantity of information that has to be gathered. It is rather a problem relating to the quality of information: individuals from parallel legal regimes cannot compare different rules because they are unable to assess the characteristics and performance of the norms used in the different systems. Individuals cannot understand the meaning of these rules, in particular their convention dimensions. Furthermore, they are unable to infer this meaning from the observation of the behaviour of others (Josselin and Marciano, 1995). In other words, they face the problem raised among others by Legrand (1997) when he argues that 'legal transplants' are impossible: a rule generated in one context cannot be generalized in order to be used in a different context. It is as if there was no competition between the different clubs.

Obviously, there are situations in which transplants are useless. For instance, as Benson rightly notes, there are certainly no reasons to transplant the rules used between diamond merchants into the group of oil traders (Benson, 2000). The transaction costs as well as the costs of adaptation that would result would obviously exceed all the benefits that such a transplant could create. Other instances can be quoted: ethnic or religious differences may act as barriers to a possible comparison of the rules used in different jurisdictions. On the other hand, in the perspective of the creation of a harmonized legal system, as in Europe, it may be necessary to avoid diversity degenerating into heterogeneity. A social contract would then be necessary in order to ensure the publicity of the law and the generalization of its meaning among its potential users.

\section{Legal Arbitrage, Information Costs and Competition}

Even if one assumes that individuals live in a world of homogeneous legal rules and that asymmetries of information do not prevent individuals from comparing them, legal arbitrage may nonetheless be difficult because of the existence of information costs. Different methods for lowering information

\footnotetext{
1 Although competition may still exist inside a given system when the allocation of competences among the jurisdictions is not tightly established.
} 
costs associated with alternative legal rules can then be envisaged. Standardization is one of the most frequently discussed solutions (see for instance Van den Bergh, 2000). The European law provides many illustrations of the willingness to create a 'level playing field'. Environmental law, as we will see latter, is one of these domains. Corporate law may also be cited as an other area in which standardization has an important role to play. Company laws in Europe are constructed to provide harmonization. The Treaty of Rome, with articles 54 and 58, acknowledges that federating nations requires the creation, not to say the construction, of a common market. The extent to which it can and should apply to law remains largely undetermined. The present book may contribute to a better understanding of this problem.

These instances of what has been called 'negative integration' illustrate the purpose that has been pursued by the European legislators, namely to remove all internal barriers to trade, thereby allowing the different legal producers to effectively and efficiently compete. However, standardization does not necessarily imply total and centralized harmonization of rules and may not be aimed at the suppression of legal competition. As, Van den Bergh puts it, 'competition and harmonization may be complements, rather than substitutes' (2000). Harmonization may provide a sound basis for further competition, which is all the more important since transaction costs often contribute to weaken the efficiency of market forces.

\section{Legal Arbitrage, Transaction Costs and Competition}

However important information costs can be, they are neither the sole nor the most decisive costs that affect legal arbitrage. Of equal importance is the second type of costs, namely the transaction costs related to the effective possibility given to the individuals to choose their preferred legal rules. Indeed, citizens dissatisfied with the law produced by 'their' local government must have the possibility to move into a different jurisdiction. Exit and inter-jurisdictional migration are thus important modes of legal arbitrage and therefore important causes for competitive pressures. It has frequently been argued that a major difference between institutional competition and ordinary market competition 'lies in the territorial nature of governments' (see Vanberg and Kerber, 1994). In this perspective, citizens have to change their residency in order to be relieved of the authority of a particular government, and the sunk costs resulting from exit may not be compensated by the benefits expected from a change of legal regime. It is most likely that 'people may stay even if the (legal) regime does not suit their need optimally [. . . ] Thus, the legal regime may not be decisive [because] ... job location and residence are that important in reality, there is often little left for people to choose' (Faure, 2000; see also Rose-Ackerman, 1992). Therefore, when considering legal competition, the individual elasticity 
of location relative to legal rules may be much closer to zero than for any other good. It happens that individuals are not necessarily interested - aside from the fact that individuals may not have the possibility to be mobile, as is stressed by many opponents to inter-jurisdictional competition - in arbitraging between different legal systems. Hence the reduction of competitive pressures or even the absence of competition, even if law is produced by decentralized legal clubs.

Now, one should not overemphasize the transaction costs resulting from the necessity to move from one jurisdiction to another and, thus, restrict attention to physical mobility as a source of competitive pressures on lawmakers. There indeed exist institutional procedures that can make competition effective even if physical mobility is impossible.

\section{Legal arbitrage without physical mobility: functional legal arbitrage}

First, some authors have proposed to envisage governments without territorial monopolies (Frey, 2001). The perspective of FOCJ or functional governance can be envisaged as a means to reduce the importance of the constraint of physical mobility and to restore institutional arbitrage (Frey and Eichenberger, 1995, 1996, 1997). Now, functional arbitrage is particularly well suited to legal competition which indeed does not necessarily imply physical mobility. Firms or citizens may change their residency or location but most of the time, legal competition is a-territorial and individuals or firms are authorized 'to select the jurisdiction whose principles are to apply to their transaction or business' (Ogus, 1999, p. 408). Of course, functional arbitrage is not likely to solve all the problems resulting from the costs of mobility and remains limited to the problems resulting from transaction costs. In the case of heterogeneous rules and asymmetric information, or when there exist high information costs, functional arbitrage faces the same difficulties as spatial arbitrage does. It nonetheless remains that functional legal arbitrage increases the domain of competition, by allowing individuals to refer to many different and parallel systems of law.

However, functional legal arbitrage may be at the origin of another type of difficulty. Indeed, when physical mobility is at stake, an individual who decides to move to another jurisdiction bears himself the costs of change. By contrast, functional arbitrage imposes costs even on immobile residents for it creates uncertainty and variability with regard to the legal framework that organizes individual behaviour and relationships with others. The role of uncertainty in the individual choice of a legal system and its influence on competition is at the core of Sophie Delabruyère's chapter. She analyses how and how far uncertainty reduces the scope of competition. More precisely, the chapter discusses two forms of uncertainty. First, uncertainty may stem from the fact that an individual ignores the rule that is likely to be used in a possi- 
ble litigation. Then, should a dispute arise and anticipating a possible disagreement on the legal system with which they would settle the dispute, individuals are likely to prefer standardized norms. Second, uncertainty may be caused by the fact that, before being confronted with a legal problem, individuals ignore the existence and the nature of the problem and thus the legal solutions as well as their preferences with regard to these solutions. In this perspective, an individual may not be able to choose ex ante a legal system, impossible that it is to know what are the gains to be maximized. This calculus reduces the competitive pressures that exist on the legal producers. The latter may then be induced to propose general rules to nonetheless attract possible litigants. In both cases, Delabruyère argues that a constitutional framework would reduce these two sources of uncertainty, thereby permitting competition to develop. In other words, competition has to be 'organized'.

\section{Collective legal arbitrage: The role of secession}

When high transaction costs reduce individual mobility, limit the freedom to choose a legal system and therefore prevent legal arbitrage, one can envisage a collective solution under the form of a secession. Thus, as a source of competitive pressures, the right to secede is an important means to control governments. The argument has been developed particularly with regard to the making of the European Institutions. Bernholz (1991) argues that the right to secede should not be given to member-states but to any subgroup in the European Union that exceeds a certain number of members. Typically, the idea that regions could secede from their state or even the European Union fits into this framework. In this perspective, Drèze (1993) proposes a system allowing 'quasi-secession' (to borrow a word from Brosio and Revelli, 2000), in which some local jurisdictions could claim a direct constitutional link with the central government and the suppression of any link with a national government. In the case of Europe, Drèze then proposes to define a 'status of regions of Europe': regions could move from a national state to the European one: 'A geographical area, currently part of a member state of the European Community [...] could henceforth belong to the community directly without being any longer part of a member state' (1993, p. 265). In other words, some kind of secession could be authorized to take into account specific regional characteristics.

Part of the problem indeed consists in asking which are these areas that could be interested in such a status. Drèze envisages the case of Corsica or Vlanderen as regions that could claim it. A justification can be proposed on the argument that peripheral regions are characterized by preferences and costs of control that do not correspond to those of 'central' regions (Josselin and Marciano, 1998, 1999). That of course does not comprehend all the aspects of the problem. Will those regions really ask for such a status? Aren't there other 
types of regions that would consider quasi-secession? Furthermore, Brosio and Revelli envisage the possibility of 'opting out' for 'those regions where per capita income is above the national average of the member states in which they are located'. They thus 'consider a region belonging to a member state of a supranational political entity such as the European Union, [whose inhabitants] for ethnic, linguistic or geographic reasons, ... cannot move from the region where they reside to any other region of the state [. . .] The residents in the region can decide by majority voting whether to opt out of the member state [...] or to be part of the member state and join its income redistribution system' (Brosio and Revelli, forthcoming 2003).

Interestingly, there is some ambiguity as to the ability of secession to restore legal arbitrage through 'vertical mobility'. It may increase competition between more independent regions (enhancing Tiebout properties of competitive governments). At the same time, the national levels would lose part of their prerogatives, which would be both an incentive and a distortion of the existing system of checks and balances.

Thus, legal arbitrage seems to function through physical or, more probably, non-physical forms of mobility. Nevertheless, it is crucial to design a kind of constitutional framework whose goal is to ensure or restore competition by allowing individuals to compare the different rules (by lowering the costs of information) as well as by permitting them to effectively choose between these rules. We must then assess the consequences of these individual or regional pressures. The next section thus analyses the reactions of the lawmakers to the behaviour of the consumers.

\section{BEHAVIOUR OF THE LAWMAKERS AND THE CONSEQUENCES OF LEGAL COMPETITION}

As was said above, competitive pressures are a major source of efficient legal change. Not only are lawmakers motivated to innovate but also these innovations are assumed to lead to 'new superior outcomes' (Vanberg and Kerber, 1994, p. 208; emphasis added). A positive interpretation of competition thus insists on the fact that 'Good rules may spread as one group emulates those rules that prove effective in another group' (Benson, 2000, p. 8). The analysis clearly rests on an evolutionist argument according to which efficient rules are selected. Now, the problem does not only lie in the difficulty to evaluate what a 'new superior outcome' means but also in the fact that doubts have frequently and repeatedly been cast upon the efficiency of evolutionary processes.

Indeed, many argue that competition could certainly degenerate into a destructive process, characterized by a prisoner's dilemma, whereby countries 
or local governments fail to enact or enforce efficient legislation. Lenient rules not only attract newcomers but also transfer the costs (at least a part of them) to the neighbouring jurisdictions. These strategic behaviours can myopically be seen as beneficial by some jurisdictions, but others will soon be lured into grabbing short term benefits. It is the famous race-to-the-bottom argument. This has been analysed with regard to some issues such as the gambling legislation in the USA, where it seems that competition has resulted in the promotion of more permissive legislation. The race-to-the-bottom argument has also been analysed in other domains, such as product liability (Faure, 2000) or environmental issues. In the present volume, Faure and De Smedt take the opportunity of discussing the White paper on environmental liability to restate the question. In analysing the fear that 'local governments ... compete with lenient environmental legislation to attract industry' (Faure and De Smedt, this volume), they show that there are no reasons to be too pessimistic. Their chapter confirms the absence of 'evidence that, under competition, the feared race to the bottom is more than theoretical' (Scott, 2000, p. 204). Moreover, Faure and De Smedt note that the problem has rarely been raised by the European Institutions in terms of destructive competition but rather in the perspective of harmonizing the conditions of competition. However, they remark that, on the one hand, there is no direct and causal link between the existence of different rules and risks of race-to-the-bottom and, on the other hand, 'it is quite possible to create a common market without a total harmonization of all legal rules' (Faure and De Smedt, this volume).

There is a second aspect of destructive competition as the result of the behaviour of the lawmakers or, more precisely, as the consequence of the process of innovation. Indeed, if competition requires innovation, innovation in turn creates differences between the rules used in the different legal systems. Obviously, differences in legal rules are both the logical consequence and the fuel of competition. However, because of the fragmentation (even if temporary) of the economic space they generate, rules are as many non-border barriers to trade. Pierre Salmon stresses this point in his chapter (see also Salmon, 2000 and Breton and Salmon, 2001). These barriers to trade and to competition may be produced by the State but are also provided by non-state organizations. It is in particular the case of the German Book Traders association whose complex system of rules is examined by Jürgen Backhaus and Reginald Hansen in their chapter. They analyse the principle according to which the resale or end-sale price charged for new books is a fixed or list price. The end price system has been operated in the German language area for more than a century and, therefore, is defended on the basis of cultural diversity. On the other hand, the system has been challenged by the European Commission for being an obstacle to competition. Backhaus and Hansen analyse the economic argumentation presented by the Commission, namely that 'cultural 
diversity is best promoted or at least not harmed by fierce price competition'. They demonstrate that to forbid the discount of books by the booksellers can be criticized as an antitrust policy designed to protect interests of the producers but has above all to be defended for the cultural issues that are involved. Price competition and economic efficiency may indeed work at the expense of cultural diversity. Existing customary norms should then be protected in the name of Hayekian organizational efficiency.

When mobility is not possible (individuals may not wish to leave their original cultural area), it does not, however, mean that competition disappears since it does not necessarily require exit. Competition without exit - provided that citizens are capable to compare the results of the various jurisdictions may work if citizens have the possibility to express their dissatisfaction and vote out the assumed inefficient legislators. Here direct competitive pressures are replaced by pressures resulting from comparison between lawmakers. The latter react to or, more precisely, anticipate the vote of the residents. Models of yardstick competition are based on this principle.

From the perspective of the behaviour of the lawmakers, legal competition cannot be considered as systematically negative. The so-called and so feared race-to-the-bottom can be considered as a myth rather than as a reality, at least whenever competition is organized (either in a spontaneous or intended way). The argument requires even more nuance when alternative forms of competition are considered. One of them is policy mimicking, whereby one jurisdiction is influenced by the actions of neighbouring jurisdictions. What Feld, Josselin and Rocaboy demonstrate in their chapter is the necessity to take strategic behaviours into account whenever competition among the few better describes the situation than a Tiebout setting. The application of a taxmimicking model to the French regions shows that the devolution process engaged in this country brings about an overall convergence of rates at higher levels than before decentralization. This kind of spontaneous and strategic harmonization provides a significant lesson for the law market. If one cannot be certain that competition will lead to superior outcomes, on the other hand, there are no reasons to condemn legal competition per se for its expected negative and destructive results. At the same time, the Tiebout setting must not hide alternative forms of competition that may prove even more accurate. Any governmental intervention must take account of it when organizing the market for law.

\section{STATE INTERVENTION}

To prevent economic inefficiency and to help preserve organizational efficiency may be the task of governmental intervention. Static arguments rest on 
the public good nature of law as well as on the external effects it breeds. Further, the process itself of centralization is to be questioned. If legal competition must be organized, the dynamics of this organization must be assessed since it might in return threaten competition.

\section{An Economic Account of State Intervention: Market Failures in the Provision of Law}

It has frequently been argued that the model of pure legal competition, just like pure competition on ordinary markets, cannot comprehend all the aspects of the provision of law. In particular, there exist market failures that may be cured by the intervention of the State.

First, the nature of law is at stake. Legal competition works because legal rules are considered as club goods in a Tiebout setting. Now, law may also be viewed as a pure public good. The argument has been used by the advocates of a federal constitution during the constitutional debates that prepared the shift from a confederation to a federation in the USA at the end of the 18th century. In particular, the creation of the US Supreme Court of Justice has thus been justified: provision of law has to be federal rather than local '[t]o avoid the confusion which would unavoidably result from the contradictory decisions of a number of independent judicatories' (Federalist Paper 22, 1987, p. 182). Typically, the argument refers to the public good nature of the law. Beside law provision by the State and by Parliament, court decisions can also be considered as public goods. Indeed, as said by Cooter and Rubinfeld (1989, p. 1070), 'from a social point of view, trials are a mechanism of collective choice' for 'the production of justice has positive side effects which go beyond the private interests of the parties seeking to resolve their dispute' (Mühl and Vereeck, this volume; see also Vereeck and Mühl, 2000). Furthermore, as noted by Mühl and Vereeck, 'the use of information embodied in a verdict is non-rivalrous and the exclusion of future litigants from that information is undesirable' (this volume). The publicness of law may then imply production by states. In practice, the European states do subsidize court services. However, as a consequence of this subsidization, the demand for trials increases, creates court delays, thereby reducing the quality of the legal system. Thus, government intervention, due to the collective nature of the legal rules, creates inefficiencies in the legal market by increasing the delays required to render justice. The existence of these delays then implies the payment of judicial interests. If one moves to competition between different legal systems, hence between different judicial interest rates, the analysis made in this volume by Mühl and Vereeck advocates that one has to favour the harmonization of these rates among the members of the federation.

Second, the pure decentralization setting cannot comprehend spillovers. 
Because of the transboundary nature of the corresponding externalities, environmental matters are one of the subjects in which a centralized provision of rules seems to be the most justified: 'This corresponds with the basic insight that if the problem to regulate crosses the borders of competence of the regulatory authority, the decision-making power should be shifted to a higher regulatory level, preferably to an authority which has jurisdiction over a territory large enough to adequately deal with the problem' (Faure and de Smedt, this volume). For instance, as Faure and de Smedt analyse it in their paper, it has been one of the justifications put forward by the promoters of the White Paper on Environmental Liability; thus, paragraph 6, dealing specifically with the subsidiarity issue, states that a directive would be necessary 'to avoid inadequate solutions to transfrontier damage'. Faure and de Smedt add that 'The Commission firmly states that national legislation cannot effectively cover transboundary environmental damage as various watercourses and protected habitats cross the borders of the Member States' (ibid.). However, one has to note that not all environmental problems have a transfrontier nature (Oates and Schwab, 1988). Furthermore, as Faure and de Smedt demonstrate 'some have warned that the argument that centralized powers are necessary to deal with transboundary problems should not be accepted too easily' (this volume; see also Van den Bergh, 1998).

These two sets of arguments cannot allow a definite and clear-cut conclusion about the standard public goods - externalities for the intervention of the State. One has to find other rationales to explain centralization in the provision of rules.

\section{The Limitation of Legal Competition and the Dynamics of State Intervention}

A first argument is that central legislators want to protect citizens. For instance, Faure and de Smedt argue that the willingness to guarantee the citizens a similar, or at least basic, environmental quality has to be viewed as an explanation for the centralized provision of environmental legislation. The argumentation rests on the assumed efficiency of the central government and, as a corollary, acknowledges the inefficiency of the decentralized provision of rules. It is another form of the race-to-the-bottom argument. Furthermore, it is assumed that the central government acts on behalf of the citizens. Then, it introduces an agency problem. Are the citizens, namely the political principals, certain that their political agents behave in conformity with their mandate? Such an argumentation opens an interesting path to understanding the process of centralization in the provision of law.

The phenomenon of a centralized (hence monopolized) system of lawmaking may be explained by an inefficient agency contract through which the 
principals are incapable of controlling the behaviour of their agents. The latter, taking advantage of their information and position, themselves increase their own prerogatives. As we have shown elsewhere, the agency relationship is reversed since the agents may behave as a principal (Josselin and Marciano, 2000). In these situations, the discretionary power of the agent is induced by the particular structure of the agency relationship; it is the reason why this kind of discretion has been labelled 'structure-induced discretion' (Steunenberg, 1996). The model can, in particular, be applied to the behaviour of the European Court of Justice (Josselin and Marciano, 2001) or may be extended so as to include the behaviour of other components of the European institutions such as the Brussels bureaucracy. Bureaucracy is indeed frequently pointed out as a source for centralization in international or supranational organizations (see in particular Vaubel and Willet, 1991; Frey, 1997; Vaubel, 1994, for an application to the European Union). The problem is that bureaucrats are unelected agents and therefore cannot be controlled like other politicians. With regard to the European decision-making process, three procedures exist that are assumed to allow the control of the European Commission: the advisory committee procedure, the management committee procedure and the regulatory committee procedure. In their chapter, Schmidtchen and Steunenberg evaluate these procedures as different ways to induce the compliance of the agent - the European Commission - with the preferences of the principal - the Council. They show that the most restrictive procedure is the regulatory committee procedure, through which 'the Commission may only implement a proposal when the committee presents a positive opinion; in case of a negative opinion, the Commission has to submit its proposal to the Council' (Schmidtchen and Steunenberg, this volume). Obviously, the complexity of intricate agency relationships pave the way for centralization. In other words, one may say that the very existence of Europe, as an institutional ambition, provides an explanation for centralization.

Such is the argument developed by Salmon. In his chapter, he considers the possibility of extending the seminal Niskanen model in order to give an account of the centralization of the European institutions. After having analysed the Niskanen model in the perspective of the European decisionmaking process, Salmon concludes that there is a 'limited' scope for bureaucratic expansionism à la Niskanen in the EU arrangements. The limitation comes from the fact this expansionism cannot be considered as out of the control of the European member-states. In other words, bureaucratic centralization could not have developed without the acquiescence of a majority of the member-states' governments. Salmon then offers a second level of explanation, which is that centralization in Europe results from the existence itself of a European project. In other words, it means that centralization could not have succeeded if the member-states had not behaved in a way favourable to 
centralization. The explanation thus provided is interesting for it contradicts the idea of the inefficiency of the agency contract that exists between the member-states and the European institutions. It is an explanation that allows us to consider that nations are conspiring against themselves (Salmon, 1995). Finally, Salmon adds a third level of explanation, the willingness of central institutions to centralize competences that belong to local governments to allow themselves more facility to 'implement [their] policy preferences' (this has been the attitude of Margaret Thatcher and of Ronald Reagan). It contradicts 'what is often taken as a natural congruence between the objective of free, unregulated markets, and that of political decentralization' (Salmon, this volume).

\section{Does State Intervention Threaten Legal Competition?}

In the preceding sections, we have insisted upon the importance of having the possibility to choose between legal producers. We have also stressed that at the same time State intervention, justified on economic or organizational grounds, was usually considered as unavoidable. These two results concur to raise the same question about the reality of competition between lawmakers when one of them is the State. The problems related to the intervention of the State are twofold. It can prevent horizontal and vertical competition. It means that, first, individuals cannot choose their preferred rules and, second, that private courts are not authorized to compete in all domains with public courts. The criticism that State intervention could be fatal to competition has especially been raised with regard to the French legal system. The criticism probably originates in the paradox that (apparently) inefficient, for being slow and expensive, public courts nevertheless dominate the legal system. The chapter by Didier Danet both refutes these criticisms and explains the domination of public courts. First, he notes that the French Civil Code (article 1134) authorizes individuals who are dissatisfied with the rules proposed by the legal codes to develop their own rules. A restriction nonetheless exists: one cannot create conventions which are likely to threaten public order and morality. However, Danet explains that courts are not prone to give an extensive interpretation of what public order means. Furthermore, public and private courts also compete with regard to the resolution of legal disputes since individuals can choose 'their' judge, as it is authorized by article 2059 of the Civil Code. It remains that, and this is the second part of Danet's chapter, one has to explain why private courts do not prevail in the French legal market. In contrast to what is usually put forward as a flaw in a centralized legal system, Danet provides examples showing that the explanation has to be found, first in the fact that private courts are not necessarily more efficient that public courts and, second, that the insecurity and high transaction costs 'inherent to the adoption of a "do-it-yourself" order' 
lead individuals to refer to the public rules and the public courts. Thus, what Danet teaches us in his chapter, is that pure competition creates costs that individuals and litigants do not necessarily want to bear. This argument is present in many of the chapters of this volume. It means that competition probably has to be carefully organized to function properly.

\section{CONCLUSION: ECONOMIC COMPETITION AND LEGAL COMPETITION}

The present book intends to demonstrate that legal competition is as important as standard economic competition in markets for private goods. Public intervention can both replace or promote market forces and the balance between the two is quite subtle. As to the markets for private goods, the European Union has already created an efficient institutional watchdog on competition. Should the same happen on the markets for law? Is the European Court of Justice entitled to take this role? Who will be the impartial spectator, spontaneously or rationally regulating the provision of law? We hope that this book will contribute to this debate.

\section{REFERENCES}

Benson, Bruce L. (2000), 'Jurisdictional choice in international trade: implications for Lex Cybernatoria', Journal des Economistes et des Etudes Humaines, X (1): 3-31.

Breton, Albert and Pierre Salmon (2001), 'External effects of domestic regulations: comparing internal and international barriers to trade', International Review of Law and Economics, 21(2): (June), pp. 135-55.

Brosio, Giorgio and Federico Revelli (2000), 'Income distribution, social security and the demand for quasi-secession', in: V. Dardanoni, G. Sobbrio, Istituzioni Politiche e Finanza Pubblica, Milano: Angeli, 231-49.

Brosio, Giorgio and Federico Revelli (forthcoming 2003), 'The political economy of regional opting out: distributive implications of a prospective Europe of Regions', Economics of Governance.

Cooter, Robert and Daniel L. Rubinfeld (1989), 'Economic analysis of legal disputes and their resolution', Journal of Economic Literature, 27: 1067-97.

Drèze, Jacques. (1993) 'Regions of Europe: a feasible status, to be discussed', Economic Policy 8(17): 265-87.

Faure, Michael G. (2000), 'Product liability and product safety in Europe: harmonization or differentiation?', Kyklos 53(4), pp. 467-508.

The Federalist Papers (1787-8), essays by Alexander Hamilton, John Jay and James Madison, edited by Isaac Kramnick (1987), New York: Penguin Books.

Frey, Bruno S. (1997), 'The public choice of international organizations', in Dennis C. Mueller (ed.), Perspectives on Public Choice, Cambridge: Cambridge University Press: 106-23. 
Frey, Bruno S. (2001), 'A utopia? Government without territorial monopoly', Journal of Institutional and Theoretical Economics, 157: 162-75.

Frey, Bruno S. and Reiner Eichenberger (1995), 'Competition among jurisdictions: the idea of FOCJ', in Luder Gerken (ed.), Competition Among Institutions, London: Macmillan: 209-29.

Frey, Bruno S. and Reiner Eichenberger (1996), 'FOCJ: competitive governments for Europe', International Review of Law and Economics, 16(3): 315-27.

Frey, Bruno S. and Reiner Eichenberger (1997), 'FOCJ: creating a single European market for governments', in Dieter Schmidtchen and Robert Cooter (eds), Constitutional Law and the European Union, Cheltenham, UK and Brookfield, US: Edward Elgar.

Josselin, Jean-Michel and Alain Marciano (1995), 'Constitutionalism and common knowledge: assessment and application to a future European constitution', Public Choice 85(1-2): 173-88.

Josselin, Jean-Michel and Alain Marciano (1998), 'Une Approche MicroEconomique des Régions Périphériques', Revue d'Economie Régionale et Urbaine, 4: 547-64.

Josselin, Jean-Michel and Alain Marciano (1999), 'Unitary states and peripheral regions: A model of heterogeneous spatial clubs'. International Review of Law and Economics, 19(4): 501-11.

Josselin, Jean-Michel and Alain Marciano (2000), 'Displacing your principal. Two historical case studies of some interest for the constitutional future of Europe', European Journal of Law and Economics, 10(3): 217-33.

Josselin, Jean-Michel and Alain Marciano (2001), 'Comportements stratégiques et production de droit: le cas du droit communautaire européen', Economie Appliquée, 54(3): 211-31.

Legrand, Pierre (1997), 'The impossibility of "legal transplants" , Maastricht Journal of European and Comparative Law, 111.

Oates, W.E. and R. Schwab (1988), 'Economic competition among jurisdiction: efficiency enhancing or distortion inducing?', Journal of Public Economics, 35: 333-54.

Ogus, Antony (1999), 'Competition between national legal systems: a contribution of economic analysis to comparative law', International and Comparative Law Quarterly, 48: 405-18.

Rose-Ackerman, Susan (1992), Re-thinking the Progressive Agenda, the Reform of the American Regulatory State, New York: The Free Press.

Salmon, Pierre (1987), 'Decentralisation as an incentive scheme', Oxford Review of Economic Policy, 3(2): 24-43.

Salmon Pierre (1995), 'Nations conspiring against themselves: an interpretation of European integration', in A. Breton, G. Galeotti, P. Salmon and R. Wintrobe (eds), Nationalism and Rationality, Cambridge and New York: Cambridge University Press, 290-311.

Salmon, Pierre (2000), 'Vertical competition in a unitary state', in G. Galeotti, P. Salmon and R. Wintrobe (eds), Competition and Structure. The Political Economy of Collective Decisions: Essays in Honor of Albert Breton, Cambridge: Cambridge University Press: 239-56.

Scott, Anthony (2000), 'Assigning powers over the Canadian environment', in G. Galeotti, P. Salmon and R. Wintrobe (eds), Competition and Structure. The Political Economy of Collective Decisions: Essays in Honor of Albert Breton, Cambridge: Cambridge University Press: 174-219. 
Steunenberg, B. (1996), 'Agent discretion, regulatory policymaking, and different institutional arrangements', Public Choice, 86: 309-39.

Van den Bergh, Roger (1998), 'Subsidiarity as an economic demarcation principle and the emergence of European private law', Maastricht Journal of European and Comparative Law, 129-52.

Van den Bergh, Roger (2000), 'Towards an institutional legal framework for regulatory competition in Europe', Kyklos 53(4), pp. 435-66.

Vanberg, Viktor and W. Kerber (1994), 'Institutional competition among jurisdictions: an evolutionary approach', Constitutional Political Economy, 5(2), 193-219.

Vaubel, Roland (1994), 'The political economy of centralization and the European Community', Public Choice 81(1-2) October, pp. 151-90.

Vaubel, Roland and Thomas D. Willett (eds) (1991), The Political Economy of International Organisations: A Public Choice Approach, Boulder, CO: Westview Press.

Vereeck, Lode and Manuela Mühl (2000), 'An economic theory of court delay', European Journal of Law and Economics 7(3), 243-68. 
Jean-Michel Josselin and Alain Marciano - 9781781950708 Downloaded from PubFactory at 04/26/2023 11:38:38AM via free access 